\title{
Russian budget structure efficiency: Empirical study
}

\author{
Alexey Kudrin ${ }^{\mathrm{a}, \mathrm{b}, \mathrm{c}}$, Alexander Knobel ${ }^{\mathrm{b}, \mathrm{d},{ }^{*}}$ \\ a St. Petersburg State University, St. Petersburg, Russia \\ ${ }^{\mathrm{b}}$ Gaidar Institute for Economic Policy, Moscow, Russia \\ c Accounts Chamber of the Russian Federation, Moscow, Russia \\ ${ }^{\mathrm{d}}$ Russian Presidential Academy of National Economy and Public Administration, Moscow, Russia
}

\begin{abstract}
This paper investigates the economic efficiency of Russian public expenditures in 20022016 by estimation of their multiplicative impact on the GDP level and economic growth. We use the empirical methodology based on Corsetti et al. (2012). We estimate a number of fiscal multipliers: on national security, law-enforcement activity, national defense, education, health care and sport and road infrastructure. For assessing the influence of budget structure on long-term economic growth rates, we estimate the SVAR model in which GDP growth is a structural variable. The research shows a positive influence of budgetary resources redistribution from non-productive government expenditures to productive ones on economic development.
\end{abstract}

Keywords: VAR, time series, fiscal policy, budget maneuver, national budget, structure of government, economic growth.

JEL classification: C32, H11, H30, H61.

\section{Introduction}

The scientific discourse about the scope and relatively optimal composition of government spending that is feasible for a given country's level of development, both in general and in terms of particular areas and items, has been on-going for a long time (see Lucas, 1988; Barro, 1991; Barro and Lee, 1993; Tanzi and Zee, 1997; Iradian, 2007; World Bank, 2006; 2007; Moreno-Dodson, 2013). No consensus of opinion has, however, been reached on the matter thus far. The available empirical experience (see Lucas, 1988; Aschauer, 1989; Barro,1996; Barro and Sala-i-Martin, 1995; Feldstein, 1996; Alesina et al., 1999; Devarajan et al.,

\footnotetext{
* Corresponding author, E-mail address: knobel@iep.ru
} 
1997) only reliably points to a certain level of government spending (as a share of GDP) below which increased spending encourages economic growth, but above which it has an adverse impact on economic development. This level may differ significantly between developing and developed economies. From 2010 to 2017, Russia's total government spending was between $34 \%$ and $38 \%$ of GDP, a level above which, according to a number of economists (see Idrisov and Sinelnikov-Murylev, 2013), increased spending would fail to encourage economic growth under current institutional conditions.

The question how the composition of government spending impacts economic development yields no straight answer as well.

In determining the optimal amount of budget spending on a certain area, a comparison of the volume of expenditures with the results achieved using those funds would be correct from a methodological point of view (see Knobel and Sokolov, 2012). However, while for some areas of budget spending, the result can easily be identified within the current period (e.g. social spending automatically ensures an observable level of income received by a certain category of citizens) or with a certain time lag (healthcare spending may result in longer life expectancy, increased birth-rates, lower infant mortality; law enforcement expenditures may reduce crime within the country, but the result could only be observed after a few years), with respect to spending on areas such as national defense, there are hardly any reliable quantitative indicators which could unambiguously determine the efficiency of budget spending (Barro, 1991; Dicle and Dicle, 2010).

The purpose of this work is to analyze the economic efficiency of government spending in Russia between 2000 and 2016 by estimating its multiplicative effect on the GDP and economic growth. In particular, the article attempts to analyze the efficiency of government spending in Russia based on SVAR models, in terms of the impact of its composition on economic development. In addition, the article also investigates the potential economic implications of a budget maneuver in favor of productive expenditures and estimates the impact that changes in the general government budget structure during the past few years have had on economic growth.

\section{Basic approaches to analyzing the efficiency of a nation's budgetary spending through a multiplier estimate. Global experience}

Government spending is an important component of any country's GDP. According to the well-known macroeconomic equation, $Y=C+I+G+N X$, where $Y$ is output, $C$ is consumption, $I$ is investments, $G$ is government spending and $N X$ is net exports. Government spending was $34.6 \%$ of the Russian GDP in $2017 .{ }^{1}$ In other countries, government spending ranged between $20 \%$ and $55 \%{ }^{2}$ of GDP.

The active application of fiscal policy during the global financial crisis in 2008 and 2009 gave rise to a new wave of scientific discussions about its opportunities and efficiency. The main question is: how does increasing government spending today affect output in the future? In economics, this effect is measured by calcu-

\footnotetext{
This figure reflects total government spending, including transfers to households, which are included in the GDP as household spending.

2 World Bank statistics (WDI On-line).
} 
lating a government spending multiplier, which describes the ratio of incremental GDP from an increase in spending. There is a difference of opinions amongst economists as to whether the government spending multiplier should be more or less than one and whether any deviations from one are admissible in terms of budget spending efficiency.

In theory, an answer can be found through modeling, although any conclusions from a model would depend heavily on the original assumptions. To confirm this statement, we consider the aforementioned equation: $Y=C+I+G+N X$, which means that everything that is produced $(Y)$ must be consumed $(C+I+G+N X)$. We will assume that government spending is increasing and try to determine its effect on GDP.

The first part of the equation represents the demand for goods and services in an economy over a certain period. Since government spending is a component of that demand, its increasing has a directly positive impact on it. However, increasing government spending has an indirect impact on the private sector, which determines the other three components of demand.

First, higher government spending will have a negative effect on household consumption, since any increase in government spending should be counterbalanced by higher total tax revenues, either simultaneously or with a certain lag. In both cases, the disposable household income will fall, followed by consumption, which is caused by the income effect. Under standard assumptions, when the Ricardian equivalence is met, households fully offset increased government spending by reducing consumption to match. This enables them to save more to cover future tax increases. This case of full substitution relies on a number of assumptions which are not met in reality. Accordingly, consumption will decrease to a lesser extent than the increase in government spending.

Second, increasing government spending adversely impacts business investment activity due to the expectation that their respective taxes will increase in the future. Evidently, these taxes reduce expected returns on projects, thereby discouraging investments. Thus, government consumption displaces private investments, which, in the long run, leads to a poorer choice of investment projects and, accordingly, lower returns on investments.

Third, an increase in government spending, through the effect described above, would reduce demand for imports. This will be accompanied, however, by rising interest rates due to a higher demand for money caused by the increasing nominal GDP that resulted from higher government spending, and the national currency strengthens, leading to higher imports. Thus, the resulting change in imports will be insignificant, while the strengthening of the national currency will, in turn, inevitably lead to reduced exports.

Accordingly, an increase in government spending can be expected to have an adverse effect on household consumption, total investments and net exports. Consequently, the only component driving an increased demand is government consumption itself.

However, for the sake of the complete picture, the impact of government spending on the other part of the equation, i.e. on supply, needs to be taken into account. Macroeconomic theory determines the supply of goods and services through three variables: production technology, capital and efficient labor. Increasing any of these variables triggers an increase in output. 
Production technology comprises knowledge which enables an economy to produce more with fixed amounts of capital and efficient labor. Technology is assumed to improve constantly. Depending on the model, this process may be random or deterministic. However, in both cases, higher government spending has little or no impact on technology (except for increases in R\&D spending).

Similarly, theoretical models assume that capital changes slowly. New buildings and equipment take time to build and install; investment projects take time to plan, obtain approval and implement. Therefore, capital is assumed to be fixed in the short run, i.e. not significantly impacted by government spending.

On the other hand, efficient labor, termed to represent the number of hours worked subject to differences in workforce skill levels (engineering hours cost more than manual labor hours), is a variable that can adapt to changes in economic conditions in the short-term. Its flexibility results from the fact that new workers can be hired quickly, while those currently employed can be transferred to parttime or dismissed. Accordingly, a question arises as to whether higher government spending will lead to more hours worked and, consequently, to higher output. As usual, the answer is contingent on the magnitude of several countervailing effects.

On the one hand, a reduction in disposable household income, due to an expected increase in tax rates, forces households to reduce their leisure time and to increase their working hours (income effect). On the other hand, an increase in taxes leading to a decrease in household wages will substitute working hours with leisure (substitution effect). Thus, the total effect on labor supply depends on which of the two effects proves to be stronger. It should be noted that if government spending is not funded through raising current taxes, the substitution effect will be insignificant, while the income effect will result in a higher supply of labor and, consequently, goods and services.

The total effect of increased government spending on the GDP is driven by the magnitude of all of the above effects on the supply of and demand for goods and services. To increase government spending means to directly increase demand. However, this direct impact on demand is offset by decreases in other components of demand. Influence through supply may either increase or decrease the efficient working hours. To balance the supply of and demand for goods and services, the model usually includes a variable that can be easily adapted to changes in the economic situation. This variable is usually represented by the real or nominal interest rate. An overview of theoretical models (Ramey, 2011) suggests that, in theory, we can obtain a sufficiently wide range of multiplier values depending on the funds used to finance government spending and on other factors. Unfortunately, this range is so wide as to preclude a definitive answer regarding whether higher government spending will lead to GDP growth.

Since theory fails to provide an unambiguous answer to the question regarding the sign and value of the multiplier, an attempt needs to be made to find an empirical answer. At first, it seems possible by comparing data sequences based on the amount of government spending and GDP and observing whether GDP grows above its usual trend when government spending is on the rise. However, a number of problems complicate this task.

For example, if the data shows a correlation between government spending and GDP trends, we cannot definitively state that GDP growth is caused by increasing government spending as the situation may be reversed, i.e. increased government 
spending is caused by GDP growth. Here we can circumvent the causality problem by focusing the estimate of budget spending efficiency on the financed areas and items which are known to be immune to GDP trends.

Another complex problem for developing an empirical estimate of the effect of increasing government spending is the expectation of economic agents. The government budget is usually finalized a few quarters before its execution, enabling households and firms to adjust their behavior in the present time, thanks to their knowledge of the expected economic events. For example, firms can create jobs in advance and procure more intermediate products to be prepared in advance for near-term expected growth in demand for their products. Also, the newly hired workers will begin to spend their wages on goods. Therefore, the effect of increased government spending may become visible in the current period, causing an under-estimation of the government spending multiplier on the GDP.

One approach to an empirical estimate of the multipliers that addresses the above issues is vector auto-regression (VAR), a statistical method of identifying correlation between data. When using large data sequences on government spending, GDP and a number of other variables, the VAR method enables the user to assign each variable a number that shows how even an insignificant change in the variable affects the GDP. To remove the influence from expectations by economic agents, we make a number of assumptions regarding how aware of fiscal policy economic agents are and introduce a limitation on the time when government spending can affect the GDP. The government spending change process in the VAR model is usually partially deterministic. Knowing the configuration of the government spending process, economic agents are assumed to be able to predict its pre-determined portion, but unable to predict the random portion, referred to as the "shock." Therefore, the problem of agent expectations can be solved by identifying shocks and measuring the GDP's reaction. To solve the problem of endogeneity (the correlation between government spending and the GDP), we have adjusted the VAR method by introducing limitations on the correlations between variables based on our a priori assumptions. For example, the model can be so structured that only government spending shocks occurring within the past 4 quarters can affect the GDP during the current quarter.

The theoretical and empirical literature demonstrates that the value of the government spending multiplier (or fiscal multiplier) may depend on many factors which define the institutional structure of the economy. These factors include:

- the economy's degree of openness: all other factors being equal, the multiplier will be higher in less open economies (Iradian, 2007; Barrell et al., 2012; Ilzetzki et al., 2013);

- the extent of labor market regulation by the state: the multiplier will be higher in economies with strong trade unions and a higher extent of labor market regulation (Cole and Ohanian, 2004; Gorodnichenko et al., 2012);

- the level of financial market development: the multiplier will be higher in countries with less-developed financial markets (Dolls et al., 2012);

- the exchange rate: the multiplier will be higher in countries with fixed exchange rates (Born et al., 2013; Ilzetzki et al., 2013) etc.

As we can see, research favors the hypothesis that the more open and less regulated an economic system is, the less impact the overall level of government spending will have on the GDP. The empirical literature also contains findings 
stating that the fiscal multiplier depends on the stage of the business cycle, becoming higher on average during economic decline (Jorda and Taylor, 2016; Batini et al., 2012; Baum et al., 2012). Thus, the effect of fiscal stimuli on the economy may heavily depend on the fundamental factors of the economic environment.

Literature distinguishes between a short-term and a long-term multiplier, based on the mechanism of government spending impact on the GDP. Increasing government spending is believed to affect the GDP in the short-run, through greater working hours, i.e. through the amount of labor. In the long-term, government spending has an impact on the GDP through capital accumulation ${ }^{3}$ (see Ramey, 2011). Accordingly, the short-term and the long-term multipliers may differ substantially. This observation is vital for explaining the variation between government spending multipliers in various sectors of the economy.

Based on differences in the impact on capital accumulation, literature categorizes government spending into productive and non-productive expenditures (IMF, 1995; Kneller et al., 1999; European Commission, 2012; Gupta et al., 2005). Productive expenditures stimulate long-term economic growth through capital accumulation. These include expenditures on construction, infrastructure, healthcare, science and education. Accordingly, non-productive expenditures have no considerable effect on capital accumulation if they already exceed a certain required minimum. They include expenditures on security, law enforcement, national defense, utility services and maintaining the state machine. This definition means that the long-term multiplier for productive expenditures will be higher than that for non-productive ones, as evidenced by empirical studies (Bose et al., 2007; Baldacci et al., 2008; Dunne and Uye, 2010).

The above differences in the long-term effects of government spending on various economic sectors also determine the differences in the impact of expenditures on the GDP both in the long-term and short-term, as economic agents have their expectations for the future and change their behavior in the present. If agent expectations regarding future capital accumulation and GDP growth differ, based on whether the government spends 100 million national currency units to purchase military equipment or spends the same amount to buy medical equipment, then the decisions made by agents today will differ as well. Examples include business decisions with respect to investments during the current period.

If they expect the economy to grow fast in the future, agents will invest more in the current period in order to enjoy higher returns on these investments in the future. Increasing investments, in turn, have a direct impact on GDP growth in the short term due to rising total demand in the economy. Accordingly, the (indirect) effect of government spending on GDP in the short term will depend on the sector of the economy, with productive expenditures having a more significant impact on the GDP than non-productive ones. Thus, the short-term multiplier for government spending depends on the economic sector, as does the long-run multiplier.

Corsetti et al. (2012) conducted an empirical analysis of the determinants of government spending multipliers based on 1975-2008 OECD data for 17 countries. Based on their findings, the authors concluded that, first, the effect of shocks on

\footnotetext{
3 For example, increasing educational spending will increase human capital in the economy in the long run, resulting in GDP growth. In other words, the long-term multiplier of educational spending is positive.
} 
macro indicators changes systematically, due to the selected type of exchange rate (that is, on average, more government spending when the exchange rate is fixed) and, second, the government spending multiplier rises during an economic crisis.

There are a number of studies (Mountford and Uhlig, 2008; Blanchard and Perotti, 2002; Perotti, 2004; Giardano et al., 2008) which also apply the VAR approach to government spending multipliers (both generally and related to particular items) and which showed that the multiplier value varies between 0.2 and 1.0. Such a wide variation can be attributed to assumptions regarding the identification of shocks.

Aschauer (1989) uses annual US data from 1949 to 1985 to show that (a) nonmilitary expenditures are a much more significant factor in total productivity than military ones; (b) the effect of military expenditures on total productivity is not statistically significant; (c) spending on infrastructure (streets, roads, airports, public transit, water supply systems etc.) has the greatest positive effect on productivity growth amongst all expenditure types.

Based on government spending data from 30 developing countries from 1970 to 1990, Bose et al. (2007) found that only educational expenditures yielded a significant positive effect on economic growth, while the effects from other budget expenditures proved to be insignificant. By analyzing data from 118 developing countries from 1971 through to 2000, Baldacci et. al. (2008) found that educational and healthcare expenditures had a positive and significant impact on economic growth through increased capital in these sectors. Moreover, there is a correlation between spending on education and healthcare. This is reflected in the fact that more highly educated individuals demand a higher quality and quantity of healthcare services and, vice versa, a growing healthcare sector requires staff with a higher level of knowledge and expertise, obtained through education. According to the same research, raising educational spending by 1.0 p.p. of the GDP leads to an increase in per capita GDP growth rates by 1.4 p.p. over the following 15 years. Increasing government spending on healthcare by 1 p.p. of the GDP leads to annual average per capita GDP growth of 0.5 p.p. A considerable time lag was noted, during which these expenditures have a positive impact on economic growth: around $2 / 3$ of the direct impact of education expenditures is realized within the first five years, while the full effect can only be realized after 10 to 15 years.

In the empirical literature, an active scientific discourse concerning the impact of military expenditures on economic development was started by Benoit (1978), who discovered a direct positive correlation between them. This encouraged extensive research. However, no consensus has been reached on the matter so far (see Dunne and Uye, 2010). The first papers (for a review of 39 studies, see Ram, 1995) found no substantial evidence that military expenditures have a positive effect on economic growth, nor confirmed an adverse effect (for a review of 54 studies, see Dunne, 1996). Subsequent scientific findings attributed insignificant or negative impacts on economic growth (Smith, 2000). The differences between the estimates are attributable to the complexity of selecting the required variables, while government defense expenditures are too heterogeneous. The resulting negative impact was typically observed in countries experiencing military and political crises and serious budgetary constraints (Smaldone, 2006). Based on a review of 103 papers studying the effects of defense expenditures, $20 \%$ of the papers estimated the effect as positive, $37 \%$ as negative and $43 \%$ identified 
no significant connection. Estimates for a group of African countries (see Dunne and Uye, 2010) found military expenditures to have a substantial adverse effect on economic growth (the coefficient of the respective variable is -4.98). A review of 170 studies (see Dunne and Tian, 2013) obtained more stable results that relied on extensive military expenditure statistics, according to which the authors lean more towards attributing a negative impact from military expenditures on economic growth. Nevertheless, these studies still fail to solve the endogeneity problem, as they lack a qualitative instrumental variable.

Other papers include Ivanova and Kamenskikh (2011), who analyzed the efficiency of government spending in Russian from 2000 through 2010. The authors calculated both the general multiplier for the total amount of government spending and individual multipliers for areas of government spending such as the national economy, utility services, environment, welfare, culture, national defense, security, law enforcement and national affairs. To obtain the multiplier values, a two-step estimation procedure was used that has often been applied in international literature (see Corsetti et al., 2012). The value of the fiscal multiplier obtained by the authors is 0.13 , demonstrating low overall government spending efficiency. As for individual expenditure multipliers for the general government budget, the national economy, utility services and environment protection (the multiplier is 0.55 ) were the most efficient government expenditures. With respect to "power" expenditures, the multiplier was estimated at 0.29 and at 0.20 with respect to culture and the social sphere.

Drobyshevsky and Nazarov (2012) also estimated the government spending multiplier in Russia. The following data were used: total government spending for both the federal (1999-2011) and consolidated (1999-2010) budget, tax revenues in the federal (1999-2011) and consolidated (1999-2010) budgets, national defense expenditures in the federal budget (1999-2011), GDP and total household consumption (1999-2010). Quarterly per capita data and constant 2005 prices were used for all of the above variables. The authors used two to four variables and took into account between 1 and 3 lagging values. They estimated the multiplier value using the structural vector autoregression (SVAR) method and obtained the following multiplier values (using federal budget data): $0.3-0.4$ for the output multiplier and 0.2 for the consumption multiplier. In addition to an estimate of the common multiplier, they also estimated the military spending multiplier in Russia. As a result, both the income multiplier and the consumption multiplier for this section turned out to be insignificant and low in absolute value.

As we can see, there is a lot of research that deals with estimating government spending multipliers. A number of such papers studied the long-term effects of changes in government spending on the GDP, while others were dedicated to short-term effects. The main econometric difficulties in all of these works are the potential reverse causality (GDP size determines the amount of government spending), the effect of other variables (e.g. a natural disaster causing a simultaneous fall in the GDP and government spending) and the risk of under-estimating the effects of government spending due to the impact of variables which current values are determined by future expectations. Failing to take these issues into account in building and estimating models may shift the estimates.

On the whole, increasing overall government spending encourages economic growth, however, the values of government spending multipliers vary across dif- 
ferent areas. Most papers demonstrate a positive effect on economic growth from government spending on education, healthcare, science, transportation and communications. Moreover, most authors have leaned towards the opinion that increasing spending on defense and other "power" items either has no or a negative impact on economic growth. Gradually, as fiscal multiplier estimation methods evolve, the results obtained in empirical literature point more towards a positive impact from productive government spending on economic growth and a negative impact from non-productive spending.

\section{Estimations based on Russian data}

\subsection{Estimating budget spending efficiency in Russia}

Our study uses an empirical methodology based on the approach used by Corsetti et al., (2012) to estimate SVAR. This is a modification to the traditional VAR method with the difference being that it imposes additional limitations on coefficient matrices and is currently considered the most adequate tool for estimating fiscal multipliers (see Clarida and Gali, 1994; Blanchard and Perotti, 2002; Mountford and Uhlig, 2008).

We estimate expenditure multipliers for individual areas of budget expenditure: national security, law enforcement, national defense, education, healthcare, sports and road infrastructure. We chose these areas as they offer uninterrupted data sequences, are the most widely discussed and can be altered. (Unlike social spending, for example, which exerts the most pressure on the government budget, but is determined by the number of recipients under the current pension and insurance systems and is difficult to change in the medium term). In addition to standard specifications using variables such as GDP, total budget spending and budget spending for individual areas, we also used Brent oil prices as an exogenous variable. We added this variable to the equations since the Russian economy in general and federal budget revenues in particular are still dependent on the oil sector.

The estimate is based on Rosstat (Russian Federal State Statistics Service) data for the period from 2000 to 2016 in current prices and constant prices of 2008 (broken down by quarter) and on the Federal Treasury data on Russia's general government budget from 2000 to 2016. We converted the total revenue and expenditure variables by area into 2008 constant prices using quarterly data on the Russian Federation GDP deflator (Source: Rosstat).

Figure 1 shows the trends in general government budget expenditures (as a percentage of GDP) for individual areas from 2000 through to 2017. Except for the last few years, expenditures in different areas showed a strong correlation, simultaneously falling or rising following an increase or decrease in total budget expenditures. However, from 2014 to 2016, there was a distinct bias toward government spending on national defense, as these expenditures grew from $3.2 \%$ to $4.4 \%$, while other selected expenditure types either remained the same or declined during the same period. ${ }^{4}$

\footnotetext{
4 However, it should be noted that the surge of expenditures on national defense in 2016 was caused by the early realization of guarantees issued by the federal budget with respect to loans granted to companies in the military-industrial complex in 2010 and 2011, maturing in 2017 and 2018 (around $0.8 \%$ of the GDP).
} 


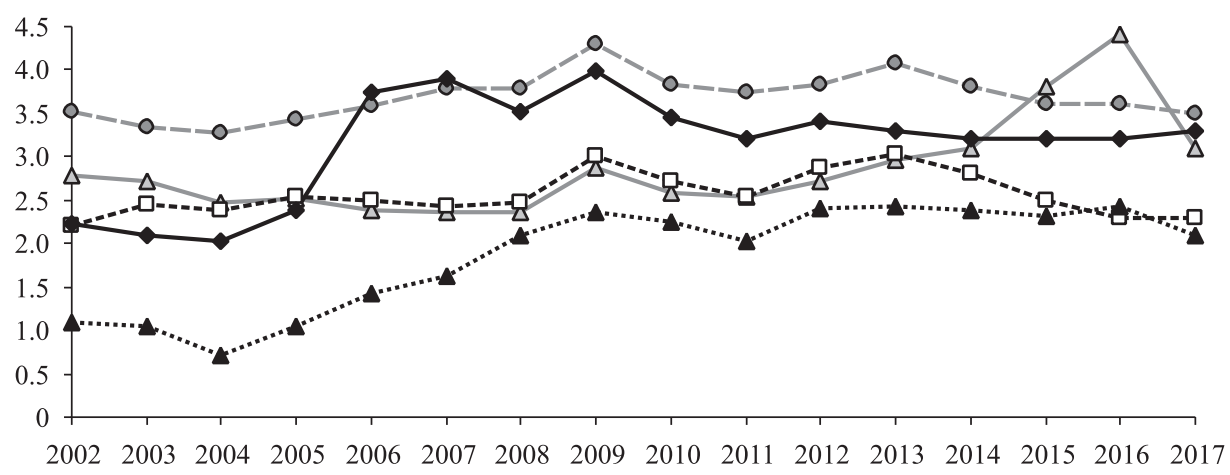

$\Delta-$ National defense
$-\square-$-. National security and law enforcement
- - - Educatiom
- - Healthcare
.....- Transportation and roads

Fig. 1. General government budget expenditure trends for individual areas (\% of GDP). Source: Authors' calculations based on Federal Treasury data.

To estimate the expenditure multipliers for various budget expenditure types, we assumed that the Russian economic system could be represented by a model consisting of two simultaneous equations: one determining budget expenditures and one determining the GDP. Both variables in the model are endogenous by default. Accordingly, to estimate this dynamic system, we needed a number of assumptions, e.g. that certain variables are exogenous in relation to others, based on the economic sense of those variables. First, we assumed the global oil price to be exogenous; second, that budget expenditures in the current period are independent from the GDP in the same period. This is a reasonable assumption, since budget expenditures in the current year are, per budget law requirements, determined by the respective laws (resolutions) on the country's budget system adopted during the previous year and are, therefore, independent from the GDP in the current period.

Thus, our model for estimating budget spending multipliers is structured as follows:

$$
\left(\begin{array}{l}
\log G_{i, t} \\
\log Y_{t}
\end{array}\right)=\left(\begin{array}{l}
\delta_{G_{i}} \\
\delta_{Y}
\end{array}\right)+\sum_{j=1}^{k} B_{j}\left(\begin{array}{l}
\log G_{i, t-j} \\
\log Y_{t-j}
\end{array}\right)+\left(\begin{array}{l}
\gamma_{G_{i}} \\
\gamma_{Y}
\end{array}\right) \log P_{o i l, t}+\left(\begin{array}{cc}
1 & 0 \\
a_{21} & 1
\end{array}\right)\left(\begin{array}{l}
e_{G_{i j},} \\
e_{Y, t}
\end{array}\right),
$$

where $P_{\text {oil }}$ is the average quarterly oil price (in USD), $G_{i}$ is the expenditures for the $i$-th area of budget spending, $Y$ is the quarterly GDP and $e$ is the structural shocks of the respective variables. The calculations are based on data from 1Q2002 to 4Q2016. The most relevant, for our purpose, is the $a_{21}$ ratio, which represents the reaction of the GDP to a single budget spending shock in the current period. An independent increase in the spending logarithm by one will lead to an increase in the GDP logarithm by $a_{21}$. In terms of the variables, it means that a $1 \%$ rise in budget spending will cause a $a_{21} \%$ rise in the GDP.

The equation (1) requires special discussion. In our model, the two main relevant variables (government spending on a selected area and GDP size) are explained by a combination of their lagging values, as accepted in most cases 
where the analysis specifications were selected (see: Clarida and Gali, 1994; Blanchard and Perotti, 2002; Mountford and Uhlig, 2008; Corsetti et al., 2012). In our case, however, we added the global oil price (expressed in USD), which is a fully exogenous variable both for government spending and GDP volume. This is the variable that largely accounted for GDP trends early in the 21 st century (see: Drobyshevsky and Nazarov, 2012; Idrisov and Sinelnikov-Murylev, 2013) and is most likely to be independent from the Russian GDP and from any amount of government spending in Russia. The very approach to VAR estimation, as a means of estimating time sequences, requires an estimate of the correlation between relevant variables, with their own lagging values carrying the most explanatory power. In this context, the dependence of the Russian economy on global prices enabled us to use a strictly exogenous variable having substantial impact on the estimated indicators.

As in all VAR models, our specification had to resolve the identification problem: the error matrix for the $\left(e_{G i, t} e_{Y t}\right)^{T}$ vector must not contain all elements with zero values. In our case, we suggested solving this problem by selecting government spending exogeneity in the current period relative to the GDP in the current period. We believe this approach to be justified, as the budget is planned in advance and the values of economic indicators in previous periods determine financing amounts in the current period, as reflected in the effect of lagging GDP values on government spending in a selected area. At the same time, government spending in the current period affects economic activity, including the GDP size.

The model was estimated for different numbers of lags (one, two and three), while the final model was selected based on standard information criteria (AIC and BIC). In order to avoid an inconveniently large number of ratio estimates, we cite estimates for only the $a_{21}$ ratio, which we interpret as the budget spending multiplier for GDP.

The GDP budget spending multiplier estimates from the SVAR model with three lags (the model with three lags was selected based on the information criteria) are given in Table 1. On the whole, the conclusion can be drawn that the results obtained are consistent with the budget spending multiplier values for the Russian Federation in other works (see Ivanova and Kamenskikh, 2011; Drobyshevsky and Nazarov, 2012). Meanwhile, the results obtained in this study are consistent with the hypothesis that productive expenditures (on education, healthcare, sports, road infrastructure and transportation) have a greater multiplicative effect on the GDP than non-productive expenditures (primarily on national defense and, to a lesser extent, on national security and law enforcement).

Table 1

GDP budget spending multiplier estimate.

\begin{tabular}{ll}
\hline Variable & Multiplier value \\
\hline Total government spending & $0.91^{*}$ \\
National defense expenditures & $0.22^{*}$ \\
National security and law enforcement expenditures & $0.78^{*}$ \\
Educational expenditures & $0.38^{*}$ \\
Healthcare and sports expenditures & $1.25^{*}$ \\
Road infrastructure and transportation expenditures & $1.64^{*}$ \\
\hline
\end{tabular}

* The ratios are statistically significant at $10 \%$.

Source: Authors' calculations. 


\subsection{Estimating the budget structure change effect}

From an economic policy point of view, it would be most relevant to analyze the comparative efficiency of various areas of budget expenditures. As mentioned above, according to the modern concepts of public finance, non-productive expenditures (unlike productive) mostly represent the ultimate consumption of resources and therefore have a weaker multiplicative effect on the GDP. Multiplier values can vary considerably between countries, but their ratios of productive and non-productive expenditures never favor the latter (see Kneller et al., 1999; Gupta et al., 2005; Bose et al., 2007; Baldacci et al., 2008; Dunne and Uye, 2010).

Thus, a change in the budget composition may have an impact on long-term economic growth through the various multiplicative effects of productive and non-productive budget expenditures.

To estimate the effect of the composition of budget spending on long-term economic growth rates, we applied the SVAR model using the GDP growth rate, rather than its size, as the structural variable:

$$
\begin{aligned}
\left(\begin{array}{c}
T_{t} / Y_{t} \\
G_{i, t} / Y_{t} \\
\left(Y_{t}-Y_{t-4}\right) / Y_{t-4}
\end{array}\right) & =\left(\begin{array}{c}
\delta_{T / Y} \\
\delta_{G_{i} / Y} \\
\delta_{\Delta Y / Y}
\end{array}\right)+\sum_{j=1}^{k} B_{j}\left(\begin{array}{c}
T_{t-j} / Y_{t-j} \\
G_{i, t-j} / Y_{t-j} \\
\left(Y_{t-j}-Y_{t-4-j}\right) / Y_{t-4-j}
\end{array}\right)+ \\
& +\left(\begin{array}{lll}
1 & 0 & 0 \\
a_{21} & 1 & 0 \\
a_{31} & a_{32} & 1
\end{array}\right)\left(\begin{array}{c}
e_{T, t} \\
e_{G_{i t} t} \\
e_{Y, t}
\end{array}\right),
\end{aligned}
$$

where $T$ is tax revenues, $G_{i}$ is expenditures on individual budget areas and $\Delta Y / Y$ is the GDP growth rate. The model was estimated based on quarterly data from 2009 to $2016 .^{5}$ We estimated cases with one and two lags (estimating more lags during the given time period does not seem possible, as the model would require too many parameters to be estimated), after which we selected the most adequate model based on standard information criteria (AIC and BIC). The lower triangular appearance of the ratio matrix before the error vector is attributed to the following identifying assumptions. The ratio of tax revenues to the GDP is the most exogenous variable and, in the current period, it depends only on its own shocks and is immune to the shocks of the other two variables. This is a realistic assumption, as a large portion of budget revenues is represented by oil revenues, which are dependent on oil prices and independent from the Russian budget and GDP. The second assumption is the same as in the previous model: government spending in the current period does not depend on GDP changes in the same period.

The relevant ratio for us here is $a_{32}$, which is the GDP budget spending multiplier. In the model (3), this ratio shows the percentage points by which the GDP growth rate would change in the current period if expenditures were increased by a value equal to one percentage point of the GDP.

Table 2 shows short-term multiplier values based on the estimate of the model (tax revenues, expenditures in individual budget areas, GDP growth rates) with

\footnotetext{
5 We intentionally chose the post-crisis period.
} 
Table 2

Estimating short-term budget spending multipliers in terms of GDP growth rates.

\begin{tabular}{lc}
\hline Variable & Multiplier value \\
\hline National defense expenditures & $-0.29^{*}$ \\
National security and law enforcement expenditures & $0.26^{*}$ \\
Educational expenditures & $0.18^{*}$ \\
Healthcare and sports expenditures & $0.09^{*}$ \\
Road infrastructure and transportation expenditures & $0.26^{*}$ \\
\hline
\end{tabular}

* The ratios are statistically significant at $10 \%$.

Source: Authors' calculations.

two lags (the model with two lags was selected based on the information criteria). As seen in the table, the multipliers for healthcare, sports, road infrastructure and transportation exceed national defense expenditures. It means that even the shortterm effect of productive expenditures on GDP growth rates is, on the whole, stronger than the effect of non-productive expenditures.

These results are, on the whole, consistent with the hypothesis that non-productive expenditures (primarily national defense expenditures) have a negative shortterm impact on economic growth rates, unlike productive expenditures (education, healthcare, transport and road construction). At the same time, we note the positive effect of expenditures for national security and law enforcement.

Together with the short-term effects on economic growth from increasing certain budget spending areas, another point presents interest, i.e. an estimate of the nature of their long-term effect, i.e. the effect of changes in a certain stationary level of the economic growth trajectory due to changes in a certain macroeconomic variable (long-term multiplicative effects). Assuming that the VAR is stationary and that the mathematical expectation of the error vector is zero $\left(e_{T, t} e_{G, t} e_{Y, t}\right)^{T}$, we can determine the mathematical expectation from the equation set as follows:

$$
\left(\begin{array}{c}
E\left(T_{t} / Y_{t}\right) \\
E\left(G_{i, t} / Y_{t}\right) \\
E\left(\left(Y_{t}-Y_{t-4}\right) / Y_{t-4}\right)
\end{array}\right)=\left(\begin{array}{c}
\delta_{T / Y} \\
\delta_{G_{i} / Y} \\
\delta_{\Delta Y / Y}
\end{array}\right)+\sum_{j=1}^{k} B_{j}\left(\begin{array}{c}
E\left(T_{t} / Y_{t}\right) \\
E\left(G_{i, t} / Y_{t}\right) \\
E\left(\left(Y_{t}-Y_{t-4}\right) / Y_{t-4}\right)
\end{array}\right) .
$$

Assuming that budget spending is increased through changing $\delta_{G i Y}$, the ratio between the effect of such intervention on the stationary level of economic growth and the effect on the stationary level of expenditures, which we can term as the long-term multiplier of such intervention, will be calculated as follows:

$$
\frac{\frac{\partial E\left(\left(Y_{t}-Y_{t-4}\right) / Y_{t-4}\right)}{\partial \delta_{G_{i} / G}}}{\frac{\partial E\left(G_{i, t} / Y_{t}\right)}{\partial \delta_{G_{i} / G}}}=\frac{\left[\left(1-\sum_{j=1}^{k} B_{j, 11}\right)\left(1-\sum_{j=1}^{k} B_{j, 33}\right)-\left(\sum_{j=1}^{k} B_{j, 13}\right)\left(\sum_{j=1}^{k} B_{j, 31}\right)\right]}{\left[\left(1-\sum_{j=1}^{k} B_{j, 11}\right)\left(\sum_{j=1}^{k} B_{j, 32}\right)+\left(\sum_{j=1}^{k} B_{j, 12}\right)\left(\sum_{j=1}^{k} B_{j, 31}\right)\right]} .
$$

Table 3 contains an estimate for calculating such long-term budget spending multipliers for various areas. 
Table 3

Estimating long-term budget spending multipliers.

\begin{tabular}{lc}
\hline Variable & Long-term multiplier value \\
\hline National defense expenditures & -0.52 \\
National security and law enforcement expenditures & -1.45 \\
Education expenditures & 0.47 \\
Healthcare and sports expenditures & 0.14 \\
Road infrastructure and transportation expenditures & -0.68 \\
\hline
\end{tabular}

Source: Authors' calculations.

It should be noted that the value of the long-term multiplier for national security and law enforcement expenditures becomes negative, unlike the short-term value (see Table 2). This result is consistent with the hypothesis that current-period expenditures in this area may lead to greater output and higher GDP growth rates, while turning out to be unproductive in the medium and long term and, together with national defense spending, slow down economic growth. The negative result for the long-term estimate of the multiplier for road infrastructure and transportation expenditures can be attributed to the unreasonable selection and inflated prices of infrastructure to be constructed (reconstructed), low real commissioning of new facilities in the sector and an exceedingly long duration of these investment projects. In this case, the result contradicts, to a certain extent, the estimates obtained for other countries (see, e.g. IMF, 2014), due to the fact that, in the early 21 st century, Russian infrastructure projects, at their implementation stage, actually created additional demand and accelerated economic growth. However, following commissioning, the economic effect from those projects could be lower than from investments in human capital. At the same time, if the efficiency of infrastructure investments can be improved in the near future, their long-term effects will not be long in coming.

Our results enable us to estimate how certain changes in the breakdown of expenditures for selected areas may lead (where planned), or have led (where actual), to changes in both short-term (5-7) and long-term (10-15) economic growth rates. Indeed, a change in the budget spending composition according to the models described and estimated above leads to changes in growth rates:

$$
\Delta \text { growth }^{S R(L R)}=\sum_{i} \xi_{i}^{S R(L R)} \times \Delta\left(\frac{G_{i}}{Y}\right),
$$

where $\Delta$ growth $S R(L R)$ is the effect on GDP growth rates in the short-term (longterm); $\xi_{i}^{S R(L R)}$ is the value of the short-term (long-term) budget spending multiplier for the $i$-th area; $\Delta\left(G_{i} / Y\right)$ is the change in the percentage of the $i$-th area of budget spending in the GDP.

Some papers (Idrisov and Sinelnikov-Murylev, 2013; Kudrin and Sokolov, 2017) analyze Russia's current fiscal policy and suggest ways to change the budget spending composition (budget maneuver). For example, Kudrin and Sokolov (2017) suggested specific measures for the budgetary stimulation of economic growth, allowing for a redistribution of expenditures in favor of productive sections: increasing educational expenditures by 0.9 p.p. of GDP, healthcare by 0.7 p.p. of GDP, roads and transportation by 0.9 p.p. of GDP; reducing expenditures on law enforcement by 0.5 p.p. of the GDP, national defense, by 0.3 p.p. of the GDP. 
While the proposed budget maneuver is related to the near future (e.g. from 2019) and is yet hypothetical, the recent years have seen an actual change in the general government spending structure: educational expenditures declined (from $3.7 \%$ of the GDP in 2011 to $3.5 \%$ in 2017), along with healthcare and sports (from $3.5 \%$ of the GDP in 2011 to $3.1 \%$ in 2017) and on national security and law enforcement (from $2.5 \%$ of the GDP in 2011 to $2.2 \%$ in 2017), whereas expenditures on national defense rose from $2.5 \%$ of the GDP in 2011 to $3.1 \%$ in 2017 , along with transportation and roads (from $2.0 \%$ of the GDP in 2011 to $2.5 \%$ in 2017).

We estimated how changes in the breakdown of budget spending from 2011 to 2017 affected GDP growth rates. To estimate their effect, as well as the potential impact of the budget maneuver, we use the formula (5), based on the values of short-term and long-term multipliers from Tables 2 and 3.

It should also be noted that we estimated the effect of changes in the composition of the general government budget only in terms of the selected five areas: education; healthcare; national security and law enforcement; national defense; roads and transportation. Our estimates lack the all-important sections of "social policy" and "national affairs." First, social policy expenditures are determined to a large extent by pension payments, which depend on the demographic trajectory and are, therefore, pre-determined in many respects. Second, the statistical data series on other areas are not stable over time, as certain sub-items of budget spending might shift between areas of expenditures from time to time. The lack of quarterly statistics on these individual sub-items precludes a correct sampling of quarterly data on certain budget spending areas over the period under review. The respective calculations are presented in Table 4.

According to our calculations, a redistribution of resources from non-productive to productive expenditures through a budget maneuver could accelerate economic growth in the short run, by about $0.3-0.4$ p.p. (on a 5-to-7-year horizon, the average annual growth rates could be higher by $0.3-0.4$ p.p.), while a change in the general government budget spending composition, occurring from 2011 till 2017, on the contrary, had a negative short-term impact of around 0.2 p.p. Naturally, long-term effects differ from short-term ones and are greater in scale.

Our calculations also demonstrate that a long-term redistribution of resources from non-productive to productive expenditures through a budget maneuver could improve long-term economic growth rates by 0.9 p.p., capable of adding $25 \%$ to $31 \%$ to the GDP in a single generation (25 to 30 years). According to our calculations, the change in the budget spending structure over the past five to six years resulted in an annual decline in economic growth rates by 0.3 p.p., i.e.

Table 4

Estimate of the short-term and long-term effects on economic growth from a potential budget maneuver and actual changes in the breakdown of budget spending from 2011 to 2017 (p.p.).

\begin{tabular}{lll}
\hline & $\begin{array}{l}\text { Short-term effect on } \\
\text { annual growth rates }\end{array}$ & $\begin{array}{l}\text { Long-term effect on } \\
\text { annual growth rates }\end{array}$ \\
\hline Budget maneuver & +0.36 & +0.94 \\
Changes in budget spending structure & -0.21 & -0.28 \\
$\quad$ from 2011 to 2017 & & \\
\hline
\end{tabular}


the transformation of the budget structure between 2011 and 2017 led to a drop in the annual economic growth rates by 0.3 p.p.

\section{Conclusion}

We attempted to estimate the effect of the budget spending composition on the economy. To this end, we estimated the fiscal multipliers for the size and growth rates of the GDP in terms of various areas of general government budget spending.

The analysis of foreign studies investigating the effect of government spending on the GDP showed that an estimate of multipliers needs to take into consideration a potential reverse causality (where the GDP size determines the amount of government spending). This paper used VAR models to estimate the expenditure multipliers for various budget areas. This approach is based on estimating a set of equations where each variable depends on the lags of all variables in the set. Since all variables in the system are endogenous (determined within the model) in this approach, the effect of one variable on another is estimated through the variable's response to a change in the other variable (which represents the residual member of the estimated equation).

According to the results of the study, the effect of an additional unit of expenditure depends on their type: non-productive expenditures ("power" items), unlike productive expenditures (investments in physical and human capital), mostly act as the ultimate consumption of resources, therefore their multiplicative effect is weaker both on the GDP and on its growth rates. This gives rise to a dependence between economic growth rates and the general government budget structure.

The multiplier estimates based on SVAR models are consistent with the values of budget spending multipliers for the Russian Federation obtained in other works (Ivanova and Kamenskikh, 2011; Drobyshevsky and Nazarov, 2012). Their values for productive areas are generally higher than for non-productive. The estimates of the effect of general government budget spending areas on GDP growth rates show that productive expenditures have a more significant impact on economic growth than non-productive.

This enables us to estimate how a budget maneuver could affect structural growth rates and how a change in the budget spending structure from 2011 to 2017 affected economic growth. It should be noted that a promising area for further research is to estimate the contribution of government spending on human and physical capital to the growth of total factor productivity.

Against the background of a deteriorating foreign economic situation, lowering budget spending may have a stabilizing effect, but, from a growth effect point of view, it is best to initially reduce non-productive expenditures while increasing or, at least, maintaining the current level of productive expenditures. For example, optimizing "non-power" items may shift the budget spending composition towards non-productive expenditures, which is unlikely to accelerate economic growth in the long run. Of course, ensuring security against internal and external threats, including through funding "power" items, is an essential condition for the state's stable functioning and for maintaining social and economic stability. However, one should exercise prudence when determining the requisite amount of non-productive expenditures, realizing the cost to be paid by the society for this or that budget spending composition. 


\section{References}

Alesina, A., Ardagna, S., Perotti, R., \& Schiantarelli, F. (1999). Fiscal policy, profits and investment. NBER Working Paper, No. 7207.

Aschauer, D. A. (1989). Is public expenditure productive? Journal of Monetary Economics, 23(2), 177-200. https://doi.org/10.1016/0304-3932(89)90047-0

Baldacci, E., Clements, B., Gupta, S., \& Cui, Q. (2008). Social spending, human capital, and growth in developing countries. World Development, 36(8), 1317-1341. https://doi.org/10.1016/j. worlddev.2007.08.003

Barrell, R., Holland, D., \& Hurst, I. (2012). Fiscal consolidation: Part 2. Fiscal multipliers and fiscal consolidations. OECD Economics Department Working Paper, No. 933.

Barro, R. J. (1991). Economic growth in a cross section of countries. The Quarterly Journal of Economics, 106(2), 407-443. https://doi.org/10.2307/2937943

Barro, R. (1996). Determinants of economic growth: A cross-country empirical study. NBER Working Paper, No. 5698.

Barro, R. J., \& Lee, J. W. (1993). International comparisons of educational attainment. Journal of Monetary Economics, 32(3), 363-394. https://doi.org/10.1016/0304-3932(93)90023-9

Barro, R., \& Sala-i-Martin, X. (1995). Economic growth. New York: McGraw Hill.

Batini, N., Callegari, G., \& Melina, G. (2012). Successful austerity in the United States, Europe and Japan. IMF Working Paper, No. 12/190.

Baum, A., Poplawski-Ribeiro, M., \& Weber, A. (2012). Fiscal multipliers and the state of the economy. IMF Working Paper, No. 12/286.

Benoit, E. (1978). Growth and defence in LDCs. Economic Development and Cultural Change, 26, 271-280. https://doi.org/10.1086/451015

Blanchard, O., \& Perotti, R. (2002). An empirical characterization of the dynamic effects of changes in government spending and taxes on output. The Quarterly Journal of Economics, 117(4), 1329-1368. https://doi.org/10.1162/003355302320935043

Born, B., Juessen, F., \& Müller, G. (2013). Exchange rate regimes and fiscal multipliers. Journal of Economic Dynamics \& Control, 37(2), 446-465. https://doi.org/10.1016/j.jedc.2012.09.014

Bose, N., Haque, M. E., \& Osborn, D. R. (2007). Public expenditure and economic growth: A disaggregated analysis for developing countries. Manchester School, 75(5), 533-556. https:// doi.org/10.1111/j.1467-9957.2007.01028.x

Clarida, R., \& Gali, J. (1994). Sources of real exchange rate fluctuations: How important are nominal shocks? NBER Working Paper, No. 4658.

Corsetti, G., Meier, A., \& Müller, G. J. (2012). What determines government spending multipliers? Economic Policy, 27(72), 521-565. https://doi.org/10.1111/j.1468-0327.2012.00295.x

Cole, H. L., \& Ohanian, L. E. (2004). New Deal policies and the persistence of the Great Depression: A general equilibrium analysis. Journal of Political Economy, 112(4), 779-816. https://doi. org/10.1086/421169

Devarajan, S., Swaroop, V., \& Zou, H. (1997). The composition of public expenditure and economic growth. Journal of Monetary Economics, 37(2), 313-344. https://doi.org/10.1016/ S0304-3932(96)90039-2

Dicle, B., \& Dicle, M. F. (2010). Military spending and GDP growth: Is there a general causal relationship? Journal of Comparative Policy Analysis, 12(3), 311-345. https://doi. org $/ 10.1080 / 13876981003714644$

Dolls, M., Fuesta, C., \& Peichl, A. (2012). Automatic stabilizers and economic crisis: US vs. Europe. Journal of Public Economics, 96(3-4), 279-294. https://doi.org/10.1016/j.jpubeco.2011.11.001

Drobyshevsky, S., \& Nazarov, P. (2012). Estimate of the budget and fiscal multiplier in the Russian Federation. Moscow: RANEPA (in Russian).

Dunne, J. P. (1996). Economic effects of military expenditure in developing countries: A survey. In N. P. Gleditsch (Ed.), The peace dividend (Ch. 23). Amsterdam: Elsevier.

Dunne, J. P., \& Uye, M. (2010). Military spending and development. In A. Tan (Ed.), The global arms trade: A handbook (pp. 293-305). London: Routledge.

Dunne, J. P., \& Tian, N. (2013). Military spending and economic growth: A survey. Economics of Peace and Security Journal, 8(1), 5-11. https://doi.org/10.15355/epsj.8.1.5

European Commission. (2012). The quality of public expenditures in the EU. European Economy. Occasional Papers, No. 125. 
Feldstein, M. (1996). The missing piece in policy analysis: Social security reform. The American Economic Review, 86(2), 1-14.

Giordano, R., Momigliano, S., Neri, S., \& Perotti, R. (2008). The effects of fiscal policy in Italy: Evidence from a VAR model. Banca d'Italia Working Papers, January.

Gorodnichenko, Y., Mendoza, E. G., \& Tesar, L. L. (2012). The Finnish Great Depression: From Russia with love. The American Economic Review, 102(4), 1619-1643. https://doi.org/10.1257/ aer.102.4.1619

Gupta, S., Clements, B., Baldacci, E., \& Mulas-Granados, C. (2005). Fiscal policy, expenditure composition, and growth in low-income countries. Journal of International Money and Finance, 24(3), 441-463. https://doi.org/10.1016/j.jimonfin.2005.01.004

Idrisov, G., \& Sinelnikov-Murylev, S. (2013). Fiscal policy and economic growth. [in Russian]. Voprosy Ekonomiki, 8, 35-39.

Ilzetzki, E., Mendoza, E. G., \& Végh, C. A. (2013). The time for austerity: Estimating the average treatment effect of fiscal policy. Journal of Monetary Economics, 60(2), 239-254. https://doi. org/10.1016/j.jmoneco.2012.10.011

IMF (1995). Unproductive public expenditures: A pragmatic approach to policy analysis. IMF Pamphlet Series, No. 48.

IMF. (2014). World economic outlook: Legacies, clouds, uncertainties. Washington, DC: International Monetary Fund. http://www.imf.org/external/pubs/ft/weo/2014/02/

Iradian, G. (2007). Rapid growth in transition economies: Growth-accounting approach. IMF Working Paper, No. WP/07/164.

Ivanova, N., \& Kamenskikh, M. (2011). Budget expenditures effectiveness in Russia. [in Russian]. Ekonomicheskaya Politika, 1, 176-192.

Jordà, Ò., \& Taylor, A. M. (2016). How big (small?) are fiscal multipliers? Economic Journal (London), 60(2), 239-254.

Kneller, R., Bleaney, M., \& Gemell, N. (1999). Fiscal policy and growth: Evidence from OECD countries. Journal of Public Economics, 74(2), 171-190. https://doi.org/10.1016/S00472727(99)00022-5

Knobel, A., \& Sokolov, I. (2012). Estimate of the medium-term fiscal policy of the Russian Federation. [in Russian]. Ekonomicheskoe Razvitie Rossii, 19(12), 23-32.

Kudrin, A., \& Sokolov, I. (2017). Fiscal maneuver and restructuring of the Russian economy. Russian Journal of Economics, 3(3), 221-239. https://doi.org/10.1016/j.ruje.2017.09.001

Lucas, R. E., Jr. (1988). On the mechanics of economic development. Journal of Monetary Economics, 22(1), 3-42. https://doi.org/10.1016/0304-3932(88)90168-7

Moreno-Dodson, B. (Ed.). (2013). Is fiscal policy the answer? A developing country perspective. Washington, DC: The World Bank.

Mountford, A., \& Uhlig, H. (2008). What are the effects of fiscal policy shocks? NBER Working Paper, No. 14551.

Perotti, R. (2004). Estimating the effects of fiscal policy in OECD countries. IGIER Working Papers, No. 276.

Ram, R. (1995). Defense expenditure and economic growth. In K. Hartley, \& T. Sandler (Eds.), Handbook of defense economics (pp. 251-273). Amsterdam: Elsevier.

Ramey, V. A. (2011). Can government purchases stimulate the economy? Journal of Economic Literature, 49(3), 73-85. https://doi.org/10.1257/jel.49.3.673

Smaldone, J. P. (2006). African military spending: Defence versus development? African Security Review, 15(4), 18-32. https://doi.org/10.1080/10246029.2006.9627618

Smith, R. P. (2000). Defence expenditure and economic growth. In N. P. Gleditsch, G. Lindgren, N. Mouhleb, S. Smit, \& I. de Soysa (Eds.), Making peace pay: A bibliography on disarmament and conversion (pp. 15-24). Claremont, CA: Regina Books.

Tanzi, V., \& Zee, H. (1997). Fiscal policy and long-run growth. IMF Staff Papers, 44(2), 179-209. https://doi.org/10.2307/3867542

World Bank. (2006). Fiscal policy for growth and development: An interim report. Background paper for the Development Committee meetings. Washington, DC.

World Bank. (2007). Fiscal policy for growth and development: Further analysis and lessons from country case studies. Background paper for the Development Committee meetings. Washington, DC. 